\title{
COMPETITIVENESS ANALYSIS OF THE TURKISH CHEMICAL INDUSTRY: A COMPARISON WITH THE SELECTED EUROPEAN UNION COUNTRIES
}

\author{
DOI: 10.17261/Pressacademia.2017.442 \\ JEFA- V.4-ISS.2-2017(7)-p.129-137
}

Elife Akis ${ }^{1}$

${ }^{1}$ Istanbul University, Istanbul, Turkey. elifakis@istanbul.edu.tr

To cite this document

Akis, E., (2017). Competitiveness analysis of the Turkish chemical industry: a comparison with the selected European Union countries. Journal of Economics, Finance and Accounting (JEFA), V.4, Iss.2, p.129-137.

Permemant link to this document: $\mathrm{http}: / /$ doi.org/10.17261/Pressacademia.2017.442

Copyright: Published by PressAcademia and limited licenced re-use rights only.

\begin{abstract}
Purpose- The aim of this study is to analyze the international competitiveness of the chemical industry of five EU member countries (Croatia, Hungary, Latvia, Lithuania, and Poland) and Turkey, which fall into 19 economies that are in the transition stage from 2nd level (efficiency- driven) to 3rd level (Innovation-driven) as stated in the Global Competitiveness Report classifying the countries according to their development levels.

Methodology- The analysis was held according to STIC Rev.4 using the 2007-2015 actual export figures of the chemicals and related products by calculating the Revealed Comparative Advantage - RCA indices explained by Balassa.

Findings- The results of the analysis show that Croatia, Hungary and Lithuania generally have rather high competitive advantage while Turkey, Poland and Latvia generally are lack of competitiveness. Turkey, Poland and Latvia have to develop their own technologies in producing high-tech, high value added goods in order to improve their chemical industries to a structure with competitiveness.

Conclusion- Chemical industry, as the raw material and intermediate goods supplier of many sectors, has a very important role both in overall production and in foreign trade. The industrial development of a country increases its requirement of chemical products. In global perspective countries aiming to improve their international competitiveness have to strengthen their chemical industry.
\end{abstract}

Keywords: Competitiveness, revealed comparative advantage, chemical industry, Turkish chemical industry, selected EU countries chemical industry.

JEL Codes: E00, F10

\section{INTRODUCTION}

Nowadays, limitless increase of impacts of globalization puts pressure on the firms, industries and the countries to strive to be competitive in order to survive in the new economy. The power of competitiveness means the purpose of deciding for the countries, regions and enterprises, how to manage their abilities in order to create long term growth, employment generation and enhance welfare. Countries when competing with each other, both countries develop; therefore power of competitiveness creates neither winner nor looser, instead leads development of all parties (Doğan, 2015:63). The economic growth achieved with the advantage of competition, increases the employment and production, in return providing economic development and social welfare enhance (Dereli, 2015: 1366). The international competitiveness of a country depends on the power of competitiveness of the firm on micro basis, and power of competitiveness of the industry and the country on macro basis.

Chemicals which are one of the important components of modern life because of their contribution to the life standards, play a crucial role in the areas from food to clean water supply, clothing and household, health and transportation, semiconductive circuits and technology (Ertek, 2014: 11). The industrial development of a country increases its requirement of chemical products. Chemical industry is contributing to the areas that are directly related with chemistry as well as to other sectors activities with its newly supplied products and newly development technologies. Shortly the countries with less developed chemical industries have a little chance to develop. 
In light of these information, our study focused on chemical sector, because of its high value added products contribution and technological improvements provided to the sectors such as energy, agriculture, transportation, food, construction, electronics, textile, and environmental protection in several countries.

In The Global Competitiveness Report, the classification made according to the development rates of the countries, Turkey and five EU member countries (Croatia, Hungary, Latvia, Lithuania, and Poland) standing among 19 economies that are in the transition stage from 2nd level (efficiency-driven) to 3rd level (Innovation-driven) is selected. At this development stage, for the 19 economies in transition period from stage 2 to stage 3, gross national income per capita is between US\$ 9.000-17.000. Besides; institutions, infra structure, macroeconomic environment, basic requirements involving health and primary education, sub index weight between 20-40\%; also involving higher education and training, goods and labour market effectiveness, financial market development, technological preparation, and market size, productive increasing sub index weight 50\% ; and operational development, and innovation and sophisticated factors sub index weight $10-30 \%$ is considered. (WEF, 2016: 38).

Foreign trade indicators are one of the main factors showing the competitiveness of country. Therefore, the main objective of this study is; to determine the competitiveness power of Turkey and the selected countries, by using their chemical industry foreign trade data, actualized between 2007-2015, and calculating their RCA indices for their chemical industries.

\section{DEFINITION AND OUTPUTS OF CHEMICAL INDUSTRY}

Chemical Industry is the total procedures and institutions producing chemical products and their derivatives. (Britannica, 2017). In general, chemical industry can be defined as the industry that uses the chemistry science for the production of chemical products. Sector, realizes the production of more than 70.000 different products, processing the several different raw materials such as petroleum, natural gas, and the mines and minerals (Duru, 2014: 5). Outputs of chemical industry can be listed in three main groups (Ertek, 2014: 11):

Basic Chemicals, includes derivatives of petrochemical goods and basic inorganic products. The basic chemicals produced in large amounts, with relatively low value added, are widely used either in chemical or other industrial productions. Basic chemicals produced using continuous production techniques and sold mainly according to their chemical component types can be easily exchanged among several producers producing same products. The demand for the basic chemicals are usually is parallel to economic growth.

Performance Chemicals, are the compounds formulated with sensitive chemicals specially produced in low amounts and with relatively higher value added, providing contribution to product performance in several different sectors. On the contrary to basic chemicals these compounds are produced with batch technology, and these chemicals are evaluated not to according to their content but according to their functions, and used in end user sectors such as, electronics, textile, paint, agriculture, petroleum areas, also for some different sectors specially used as an additive for the finished products to provide specialties such as stickiness, anti-corrosion, no flammability.

Consumption Chemicals involves the products produced directly for the end user, such as soaps, detergents, shampoos, perfumes and cosmetics.

Chemical sector is mainly using the one third of its production, as input again in chemistry industry. Apart from its own consumption area of chemical substances, consumption chemicals are mostly used in segment including the cosmetics and cleaning sectors by $30 \%$, secondly service sector by $17 \%$. Main metals, machinery and electronics $9 \%$, agriculture $7 \%$, textile $6 \%$, construction $5-6 \%$, automotive $5 \%$.

\section{TURKISH CHEMICAL INDUSTRY}

Chemical Industry which can be considered as production started only during Republic Period. Although, before the period of republic, soap, rose oil and gunpowder was produced, these products never reached an amount to be considered as industry (DPT, 2001: 3). The historical development of chemical sector in our country, can be studied under three headings within the frame work of economic policies; the period industrial plan period until the beginning of planned development period (1934-1962), from the beginning of the planned development period until the liberalization of economy (1963-1979) and the liberal economy period targeting export oriented growth open to foreign markets (after 1980).

In the first years of Republic due to insufficient capital accumulation, private sector was not able to invest to chemical industry sector. Therefore the first investments in the sector were implemented by the government to meet the semiproducts requirement. With this purpose between within the framework of 1st Industrial Plan implemented between 19341938 , the production of some important chemicals started. During above mentioned period, the studies developing in the World, regarding petroleum refining also started in our country. Governmental investments, was aiming the establishment of chemical industry, while providing the required raw materials for other sectors. Private sector investments were not 
equally in large scales but instead mostly towards the production of consumption chemicals (T.C. Kalkınma Bakanlığı, 2015: 2-3).

Between the years 1963-1979 during Planned Development model with import substitute approach, governmental investments in chemical industry increased and production of several chemical industry raw materials realized. The rubber and plastic products sector which mainly obtain their inputs from chemical industry, was restructured, petrochemical investments for providing raw material to the sector was left far behind to meet the requirements of the rapidly growing sector. As a result of insufficient raw material supply of plastics and rubber sector, import of these raw materials continued to increase. In those years, in addition to refinery investments that provide important amount of input to chemical sector, other investments such as Petlas using petroleum products have also been finalized. Also refinery integration to Petkim; was realized during so called period which currently is the only integrated petrochemical facility of the country. Despite the completion of above mentioned investments, the construction of the planned organic and inorganic facilities could not be realized (DPT, 1979: 533-534).

In 1980, after starting to follow outward oriented economic policies in the country, and in 1984, right after the publication of Customs Law, price reductions in customs tariffs related to chemical products was observed. After the decisions made and policies applied, the capacity and the production amount of Turkish chemical industry rapidly increased and in connection with this development, exports rapidly increased (T.C. Kalkınma Bakanlığı, 2015: 3). In the development plans prepared after 1980; improving private sector's role in the industrialization, to increase the share of private sector investments among total investments, to support technology transferee and development to enhance private sectors' competitiveness power (DPT, 1989: 3) to take the necessary measures to reduce the input costs (DPT, 1995: 65) and to support R\&D investments in information intensive sectors, was emphasized(DPT, 2000: 221).

Turkish chemical industry is composed of the facilities which produce various chemical raw materials and consumption goods such as mainly petrochemicals, soap, detergent, fertilizers, medicine, paint-varnish, synthetic fibers, and soda. The firms operating in the sector, varies in terms of scale and capital resources. The firms operating in the sector are mostly of small and medium size but large scale firms and multinational companies are also running their operations. Chemical industry is dependent on imports. $70 \%$ of the raw materials are imported, while only $30 \%$ is domestically supplied. The main input of plastics production is supplied from petrochemical sector at $90 \%$. Petrochemical industry is a large scale and capital and technology intensive sector. Plastics and rubber sector is more than $90 \%$ import dependent (T.C. Ekonomi Bakanlığı, 2015: 4).

Turkey Chemical Substances and Products have foreseen an export share of $0.79 \%$ for 2023 . To achieve this level, three basic areas to be focused on were determined: positioning the countries, technological development, adjustment of infrastructure and legislation. Within this scope, to use the enhanced image of Turkey is a leverage, to attract foreign capital, to increase the R\&D infrastructure investments for technological transformation, to improve of bureaucratic legislation and incentive mechanisms, to realize reforming trade agreements and to provide support to diversified finance models were underlined emphasizing their importance (Uluengin, 2012: 46).

\section{CHEMICAL INDUSTRY OF SELECTED EUROPEAN UNION COUNTRIES}

Croatia's chemical sector has a long past / tradition. The country is the land of two science people awarded by Nobel Prize in chemistry. This past indicates the accepted comparative superiority of chemical industry, with its well-educated, experienced high quality labour. The main productions of Croatian chemical sector are medicine, fertilizer, rubber and plastics, detergent, paint and varnish. Most of the firms operating in chemical sector in this country, especially the small and medium size enterprises are producing for local market. These firms are restructuring in line with the European Union's production process. Their production processes are modernized and production costs decreased. Chemical products in this country are one of the industries that exports. However, the production is dependent on imports of the raw material. Sector adversely effected from global crisis. In 2009 both imports and exports declined. Exports share decreased by 37.75 comparing to previous year, while imports decreased by 26, 4\% (Štibuhar, Picard and Kovačev, 2014: 5, 8).

In Hungary although a modernization was achieved in recent years, chemical industry history started before the World War 1st. In those years due to the lack of coal and raw materials were the main factors hindering sectoral development. After 1920, in spite of the difficulties in repairing economy, and great depression, sector realized important development. In 1929, the sector's weight was 7\% in 1938 increased to above 9\%. During World War 2nd. the sector suffered once more. During this period the one third of Hungarian chemical industry was ruined. After the 2nd World War, especially after 1960, sector developed rapidly. Even an important portion of the current production capacity was achieved in those years. After 1970 , the productivity of the sector improved significantly. In 10 years, with average $8,8 \%$ annual growth was realized in Hungary by the driving power of Petro chemical Industry. Between the years 1970-1989 Chemical Factories was established in the country. Sector today preserves its importance in Hungarian economy. Despite the fact that sector suffered from the 
severe crisis in 2009 its performance is still above the Hungarian industries and also the European Chemical industry (MAVES'Z 25, 2015: 6, 7, 12).

In Latvia chemical sector is improving. Sector is above the country's average sectoral productivity and in application of new technologies. It is one of the most powerful industries in the country. Sectoral sub branch productions are simple chemicals, paints, fertilizers, medicines, biotechnical products. Sector is considered to be export original as its share in countries exports a significant amount. However, most of its exports are to EU countries (UK Trade \& Investment, 2010: 14).

Chemical sector of Letonia, is a strong industrial sub branch, producing a wide range of products from petrochemicals to paint and household chemicals. Letonia had a strong position in chemical sector during Soviet Union period. The $25 \%$ of total medicine requirement of Soviet Union used to be produced in Letonia. In the country, chemical and pharmaceutical sectors are in the 4th rank by $7.6 \%$, in 2014 , within the total manufacturing industry, and in the 5 th rank by $6.7 \%$ from employment point of view. As of 2014, 490 firms are operating in the sector. Again according to the statistical data from 2014, chemicals and pharmaceutics exports are 39\% and 30\% respectively, being the leading sector in the total exports. The followers are plastics and rubber with $24 \%$ and $7 \%$ share in exports, respectively. The foremost export markets of Letonia are Lithuania, Estonia, and Commonwealth of Independent States (CIS) but mainly Russia, Germany, Sweden, Denmark and Poland LIAA, 2017: 1).

Chemical sector in Poland, has a past history. Petroleum was first used in Poland in a massive scale. Currently, the leading sectors in chemical industry are petrochemicals, plastics and artificial fertilizers. Pharmaceutics and cosmetics it is the care relatively in smaller scales. As of 2013, the number of firm operating in the sector is 11.000 . Chemical Industry is in the second rank in the total industry after the food sector. Sector created 247.000 employments in 2012. Labour productivity is increasing. When compared with EU Countries, has the highest labour productivity after Lithuania. Recently, tendencies regarding to increase productivity and profitability, to increase effective use of energy due to satisfy limiting environmental standards and to conform environmental requirements gained importance. (Polish Information and Foreign Investment Agency, 2013: 4,6).

\section{METHODOLOGY}

One of the important factors that determine the competitiveness of a country is its "Foreign Trade Indicators". Countries' foreign trade is based on their comparative advantages. The changes in the comparative advantages in time can be explained by Foreign Trade Figures. It is difficult to measure the competitiveness of countries at international arena since the pre-trade relative prices are not known. For this reason, Revealed Comparative Advantage (RCA) Index, which is based on real Foreign Trade Figures, is used to exhibit the international competitiveness. (Yalçınkaya, 2014: 49).

RCA index, having a leading role in this context is the most widely used approach in measuring competitiveness among other approaches. Relative export performances of countries on pre-determined commodities are tried to be determined by this approach. RCA index was first originated by Liesner in 1958, then improved by Balassa. RCA approach assumes that the actual value of comparative advantage can only be driven from the post-trade figures. The goal in here, is the determination of whether the country has comparative advantage or not, rather than to identify the underlying sources of comparative advantage (Baltacı vd., 2012: 8).

RCA index, as improved by Balassa (1965) may be expressed as follows:

$\mathrm{RCA}=(\mathrm{Xij} / \mathrm{Xit}) /(\mathrm{Xnj} / \mathrm{Xnt})=(\mathrm{Xij} / \mathrm{Xnj}) /(\mathrm{Xit} / \mathrm{Xnt})$ Here $\mathrm{X}$ indicate exports, $\mathrm{i}$ a country, $\mathrm{j}$ a good (or a sector), $\mathrm{t}$ goods (or sectors) and $n$ a group of countries (or countries in the world). In accordance with these variables, RCA is measured by the proportion of the share exports a specific product or industry in the total exports of a certain country to the share of the same product or industry in the total trade of a group of countries or the world. If the calculated index value is greater than $(R C A>1)$, it is assumed that the country has a comparative advantage in the measured area. If the calculated index value is less than $(\mathrm{RCA}<1)$, it is considered that the subject country lacks competitiveness in production of that commodity. (Fertö and Hubbard, 2002: 5; Yue and Ping, 2002: 278; Utkulu and Seymen, 2004: 8-9).

\section{DATA and EMPRICAL FINDINGS}

Data related to Turkey's and the selected European Countries' chemical industries, are acquired from the UN COMTRADE database, which was prepared by United Nations, in the scope of SITC (Standard International Trade Classification) Rev.4. Table 1 exhibits the parts and sections of Chemical Industry Commodities. 


\section{Table 1: Chemical Industry Commodities According to SITC Rev.4 Classification}

\section{SITC Rev.4}

$\begin{array}{ll}\mathbf{5} & \text { Chemicals and related products, n.e.s. } \\ \mathbf{5 1} & \text { Organic chemicals } \\ \mathbf{5 2} & \text { Inorganic chemicals } \\ \mathbf{5 3} & \text { Dyeing, tanning and colouring materials } \\ \mathbf{5 5} & \text { Medicinal and pharmaceutical products } \\ \mathbf{5 6} & \text { Essential oils and resinoids and perfume materials, toilet, polishing and Cleansing preparations } \\ \mathbf{5 7} & \text { Fertilizers (other than those of group 272) } \\ \mathbf{5 8} & \text { Plastics in primary forms } \\ \mathbf{5 9} & \text { Plastics in non-primary forms }\end{array}$

Source: UN COMTRADE Database, http://comtrade.un.org/data/, 03.03. 2017

Table 2: RCA Index for the Croation Chemical Industry (2007-2015)

\begin{tabular}{|c|c|c|c|c|c|c|c|c|c|}
\hline SITC Rev.4 & 2007 & 2008 & 2009 & 2010 & 2011 & 2012 & 2013 & 2014 & 2015 \\
\hline 5 & 1,00 & 1,03 & 0,87 & 1,06 & 1,10 & 1,08 & 1,08 & 1,02 & 1,09 \\
\hline 51 & 0,16 & 0,12 & 0,12 & 0,13 & 0,12 & 0,16 & 0,16 & 0,17 & 0,23 \\
\hline 52 & 0,49 & 0,39 & 0,25 & 0,12 & 0,11 & 0,14 & 0,34 & 0,50 & 0,25 \\
\hline 53 & 0,97 & 1,14 & 0,97 & 1,00 & 1,09 & 1,01 & 1,05 & 0,98 & 0,96 \\
\hline 54 & 0,93 & 0,90 & 0,93 & 1,24 & 1,46 & 1,66 & 1,57 & 1,41 & 1,54 \\
\hline 55 & 1,01 & 1,29 & 1,14 & 1,22 & 1,45 & 1,64 & 2,07 & 1,94 & 1,62 \\
\hline 56 & 9,31 & 5,51 & 5,24 & 6,85 & 7,73 & 8,48 & 8,09 & 7,02 & 6,55 \\
\hline 57 & 1,73 & 1,78 & 1,38 & 1,66 & 1,07 & 0,30 & 0,31 & 0,29 & 0,29 \\
\hline 58 & 0,91 & 1,07 & 0,98 & 0,98 & 0,98 & 1,10 & 1,35 & 1,51 & 1,57 \\
\hline 59 & 0,40 & 0,38 & 0,35 & 0,40 & 0,39 & 0,28 & 0,33 & 0,41 & 0,51 \\
\hline
\end{tabular}

* The table was calculated based on UN, Commodity Trade Statistics Database (COMTRADE).

Table 2 exhibits the RCA index values for Croatian chemical industry calculated for the period of $2007-2015$. These values indicate the competitiveness of Croatia on essential oils and resinoids and perfume materials, toilet, polishing and cleansing preparations (55) and Fertilizers (56) both before and after the global economic crisis, without any interruption. Particularly in the section (56) Fertilizers, it is observed that Croatia has rather higher competitiveness in comparison to other designated countries. In 2015, Croatia has competitive advantage in Chemical Industry in general and in four subsections. 
Table 3: RCA Index for the Hungarian Chemical Industry (2007-2015)

\begin{tabular}{llllllllll}
$\begin{array}{l}\text { SITC } \\
\text { Rev.4 }\end{array}$ & $\mathbf{2 0 0 7}$ & $\mathbf{2 0 0 8}$ & $\mathbf{2 0 0 9}$ & $\mathbf{2 0 1 0}$ & $\mathbf{2 0 1 1}$ & $\mathbf{2 0 1 2}$ & $\mathbf{2 0 1 3}$ & $\mathbf{2 0 1 4}$ & $\mathbf{2 0 1 5}$ \\
\hline $\mathbf{5}$ & 0,78 & 0,80 & 0,77 & 0,82 & 0,91 & 1,00 & 1,05 & 1,03 & 1,02 \\
$\mathbf{5 1}$ & 0,46 & 0,49 & 0,47 & 0,59 & 0,58 & 0,71 & 0,76 & 0,73 & 0,70 \\
$\mathbf{5 2}$ & 0,68 & 0,60 & 0,63 & 0,70 & 0,75 & 0,88 & 0,93 & 0,83 & 0,67 \\
$\mathbf{5 3}$ & 0,33 & 0,34 & 0,30 & 0,27 & 0,25 & 0,26 & 0,31 & 0,32 & 0,30 \\
$\mathbf{5 4}$ & 0,99 & 1,18 & 1,11 & 1,24 & 1,57 & 1,71 & 1,70 & 1,55 & 1,57 \\
$\mathbf{5 5}$ & 0,78 & 0,77 & 0,76 & 0,74 & 0,76 & 0,89 & 1,17 & 1,35 & 1,25 \\
$\mathbf{5 6}$ & 0,63 & 0,43 & 0,47 & 0,50 & 0,57 & 0,51 & 0,44 & 0,63 & 0,39 \\
$\mathbf{5 7}$ & 1,29 & 1,20 & 0,98 & 1,04 & 1,08 & 1,09 & 1,14 & 1,12 & 1,08 \\
$\mathbf{5 8}$ & 0,82 & 0,86 & 0,78 & 0,74 & 0,77 & 0,83 & 0,80 & 0,81 & 0,84 \\
$\mathbf{5 9}$ & 0,30 & 0,35 & 0,40 & 0,34 & 0,39 & 0,43 & 0,48 & 0,50 & 0,57 \\
\hline
\end{tabular}

* The table was calculated based on UN, Commodity Trade Statistics Database (COMTRADE).

Based upon the calculations, Table 3 reflects the most stable competitiveness of Hungarian Chemical Industry especially in Plastics in Primary Forms (57) for the period of 2007-2015. Beginning with 2008, this is followed by Section (54) Medicinal and Pharmaceutical products. However, it is indicated that only after 2012, Hungary reached to the point of comparative advantage in Chemical Industry.

Table 4: RCA Index for the Latvian Chemical Industry (2007-2015)

\begin{tabular}{lllllllllll}
$\mathbf{S I T C}$ & $\mathbf{2 0 0 7}$ & $\mathbf{2 0 0 8}$ & $\mathbf{2 0 0 9}$ & $\mathbf{2 0 1 0}$ & $\mathbf{2 0 1 1}$ & $\mathbf{2 0 1 2}$ & $\mathbf{2 0 1 3}$ & $\mathbf{2 0 1 4}$ & $\mathbf{2 0 1 5}$ \\
\hline $\mathbf{5} . \mathbf{4}$ & 0,85 & 0,95 & 0,82 & 0,78 & 0,78 & 0,70 & 0,70 & 0,71 & 0,72 \\
$\mathbf{5 1}$ & 0,27 & 0,33 & 0,31 & 0,28 & 0,30 & 0,30 & 0,23 & 0,21 & 0,21 \\
$\mathbf{5 2}$ & 1,41 & 2,15 & 0,37 & 0,22 & 0,27 & 0,15 & 0,11 & 0,12 & 0,21 \\
$\mathbf{5 3}$ & 1,61 & 1,79 & 1,44 & 1,26 & 1,17 & 1,13 & 1,28 & 1,15 & 1,12 \\
$\mathbf{5 4}$ & 1,33 & 1,32 & 1,28 & 1,41 & 1,34 & 1,00 & 1,06 & 1,03 & 0,99 \\
$\mathbf{5 5}$ & 0,98 & 1,05 & 0,90 & 0,84 & 1,02 & 0,89 & 0,93 & 1,02 & 1,03 \\
$\mathbf{5 6}$ & 0,33 & 0,80 & 0,58 & 0,50 & 0,69 & 0,51 & 0,52 & 0,99 & 1,11 \\
$\mathbf{5 7}$ & 0,23 & 0,32 & 0,38 & 0,41 & 0,32 & 0,34 & 0,30 & 0,33 & 0,36 \\
$\mathbf{5 8}$ & 1,17 & 0,96 & 0,72 & 0,97 & 0,98 & 0,99 & 0,99 & 1,05 & 1,06 \\
$\mathbf{5 9}$ & 0,96 & 1,04 & 1,01 & 0,59 & 0,90 & 1,11 & 1,03 & 0,98 & 0,89 \\
\hline
\end{tabular}

* The table was calculated based on UN, Commodity Trade Statistics Database (COMTRADE).

When we evaluate the RCA indices of Latvia via Table 4, Latvia generally seems as lacking competitiveness in chemicals and related products (5) within the considered countries. Nevertheless, in dyeing, tanning and colouring materials (53) and medicinal and pharmaceutical products (54) Latvia has a stabilized advantage before and after the global economic crisis. 
Table 5: RCA Index for the Lithuanian Chemical Industry (2007-2015)

\begin{tabular}{lllllllllll}
$\begin{array}{l}\text { SITC } \\
\text { Rev.4 }\end{array}$ & $\mathbf{2 0 0 7}$ & $\mathbf{2 0 0 8}$ & $\mathbf{2 0 0 9}$ & $\mathbf{2 0 1 0}$ & $\mathbf{2 0 1 1}$ & $\mathbf{2 0 1 2}$ & $\mathbf{2 0 1 3}$ & $\mathbf{2 0 1 4}$ & $\mathbf{2 0 1 5}$ \\
\hline $\mathbf{5}$ & 1,41 & 1,42 & 1,22 & 1,21 & 1,30 & 1,28 & 1,18 & 1,26 & 1,36 \\
$\mathbf{5 1}$ & 0,10 & 0,13 & 0,13 & 0,22 & 0,20 & 0,23 & 0,19 & 0,19 & 0,29 \\
$\mathbf{5 2}$ & 0,93 & 0,97 & 0,49 & 0,54 & 0,69 & 0,84 & 0,81 & 0,94 & 0,96 \\
$\mathbf{5 3}$ & 1,34 & 1,02 & 1,11 & 1,22 & 1,06 & 1,20 & 1,42 & 1,29 & 1,08 \\
$\mathbf{5 4}$ & 0,33 & 0,34 & 0,47 & 0,49 & 0,50 & 0,51 & 0,57 & 0,74 & 0,87 \\
$\mathbf{5 5}$ & 0,54 & 0,42 & 0,63 & 0,64 & 0,71 & 0,73 & 0,80 & 0,90 & 0,92 \\
$\mathbf{5 6}$ & 24,83 & 15,83 & 15,13 & 12,06 & 13,02 & 12,43 & 10,78 & 11,73 & 11,59 \\
$\mathbf{5 7}$ & 2,81 & 2,08 & 2,26 & 2,23 & 1,98 & 1,89 & 1,71 & 1,61 & 1,52 \\
$\mathbf{5 8}$ & 1,74 & 1,51 & 1,40 & 1,43 & 1,49 & 1,61 & 1,62 & 1,77 & 1,78 \\
$\mathbf{5 9}$ & 0,75 & 0,95 & 1,39 & 1,12 & 1,27 & 1,30 & 1,33 & 1,39 & 1,59 \\
\hline
\end{tabular}

* The table was calculated based on UN, Commodity Trade Statistics Database (COMTRADE).

Lithuania seems as having the competitive advantage in Chemical Industry generally and in its all subsections. The least index value is calculated for Organic Chemicals (51). It is expected for Lithuania to gain competitive advantage in the short run for inorganic chemicals (52), medicinal and pharmaceutical products (54) and essential oils and resinoids and perfume materials, toilet, polishing and cleansing preparations (55). Within the designated countries, Lithuania is in the state of having the highest competitive advantage. Although a slight decrease is recorded particularly in Fertilizers (56) section from 2007 to 2015, still owns a very high advantage. .

Table 6: RCA Index for the Polish Chemical Industry (2007-2015)

\begin{tabular}{|c|c|c|c|c|c|c|c|c|c|}
\hline $\begin{array}{l}\text { SITC } \\
\text { Rev.4 } \\
\end{array}$ & 2007 & 2008 & 2009 & 2010 & 2011 & 2012 & 2013 & 2014 & 2015 \\
\hline 5 & 0,77 & 0,81 & 0,70 & 0,80 & 0,86 & 0,90 & 0,90 & 0,88 & 0,82 \\
\hline 51 & 0,49 & 0,45 & 0,33 & 0,40 & 0,50 & 0,49 & 0,42 & 0,40 & 0,34 \\
\hline 52 & 0,82 & 0,83 & 0,71 & 0,73 & 0,82 & 0,94 & 0,98 & 0,92 & 0,78 \\
\hline 53 & 1,02 & 1,03 & 0,86 & 0,93 & 1,00 & 1,11 & 1,17 & 1,14 & 1,02 \\
\hline 54 & 0,31 & 0,39 & 0,36 & 0,47 & 0,46 & 0,50 & 0,57 & 0,59 & 0,51 \\
\hline 55 & 2,26 & 2,54 & 2,57 & 2,67 & 2,59 & 2,72 & 2,56 & 2,47 & 2,20 \\
\hline 56 & 2,04 & 1,68 & 0,94 & 1,25 & 1,28 & 1,39 & 1,25 & 1,25 & 1,14 \\
\hline 57 & 0,76 & 0,72 & 0,64 & 0,68 & 0,75 & 0,78 & 0,76 & 0,69 & 0,74 \\
\hline 58 & 1,74 & 1,82 & 1,54 & 1,60 & 1,73 & 1,84 & 1,87 & 1,80 & 1,76 \\
\hline 59 & 0,45 & 0,41 & 0,45 & 0,68 & 0,80 & 0,76 & 0,80 & 0,81 & 0,76 \\
\hline
\end{tabular}

* The table was calculated based on UN, Commodity Trade Statistics Database (COMTRADE).

Poland has considerable competitiveness in essential oils and resinoids and perfume materials, toilet, polishing and cleansing preparations (55), fertilizers (56) and plastics in non-primary forms (58) consistently between 2007 -2015 periods. Nevertheless is not able to reflect this advantage in chemicals and related products (5). 
Table 7: RCA Index for the Turkish Chemical Industry (2007-2015)

\begin{tabular}{lllllllllll}
$\begin{array}{l}\text { SITC } \\
\text { Rev.4 }\end{array}$ & $\mathbf{2 0 0 7}$ & $\mathbf{2 0 0 8}$ & $\mathbf{2 0 0 9}$ & $\mathbf{2 0 1 0}$ & $\mathbf{2 0 1 1}$ & $\mathbf{2 0 1 2}$ & $\mathbf{2 0 1 3}$ & $\mathbf{2 0 1 4}$ & $\mathbf{2 0 1 5}$ \\
\hline $\mathbf{5}$ & 0,43 & 0,45 & 0,43 & 0,50 & 0,51 & 0,52 & 0,55 & 0,56 & 0,53 \\
$\mathbf{5 1}$ & 0,16 & 0,18 & 0,15 & 0,21 & 0,18 & 0,19 & 0,17 & 0,16 & 0,09 \\
$\mathbf{5 2}$ & 0,33 & 0,30 & 0,30 & 0,37 & 0,35 & 0,43 & 0,40 & 0,50 & 0,91 \\
$\mathbf{5 3}$ & 0,83 & 0,91 & 0,98 & 1,11 & 1,09 & 1,14 & 1,30 & 1,23 & 1,16 \\
$\mathbf{5 4}$ & 0,15 & 0,14 & 0,13 & 0,18 & 0,17 & 0,18 & 0,20 & 0,19 & 0,21 \\
$\mathbf{5 5}$ & 1,14 & 1,14 & 1,18 & 1,26 & 1,27 & 1,25 & 1,32 & 1,37 & 1,20 \\
$\mathbf{5 6}$ & 0,39 & 0,41 & 0,28 & 0,57 & 0,40 & 0,28 & 0,21 & 0,32 & 0,27 \\
$\mathbf{5 7}$ & 0,31 & 0,33 & 0,34 & 0,39 & 0,42 & 0,42 & 0,43 & 0,45 & 0,41 \\
$\mathbf{5 8}$ & 1,98 & 2,12 & 2,05 & 2,16 & 2,32 & 2,35 & 2,57 & 2,56 & 2,26 \\
$\mathbf{5 9}$ & 0,31 & 0,29 & 0,30 & 0,35 & 0,34 & 0,37 & 0,41 & 0,39 & 0,41 \\
\hline
\end{tabular}

* The table was calculated based on UN, Commodity Trade Statistics Database (COMTRADE).

In Table 7, we see the RCA indices of Turkish chemical industry for the period of 2007-2015. Turkish Chemical Industry has high competitive advantages in dyeing, tanning and colouring materials (53), essential oils and resinoids and perfume materials, toilet, polishing and cleansing preparations (55) and particularly in plastics in non-primary forms (58). Being dominant in plastics in non-primary forms (58) sections, can be evaluated as an important advantage. Turkish chemical industry has competitiveness in the areas of specialized and high-quality chemical products.

\section{CONCLUSION}

Chemical industry, as the raw material and intermediate goods supplier of many sectors, has a very important role both in overall production and in foreign trade. There are only few commodities that can be produced without the addition of raw materials from the chemical industry. In this context; pesticides, synthetic fertilizers, veterinary medicines, synthetic fibre, soap, detergent, cleaners, plastic raw materials, human medicine industry, cosmetics industry, dye, auxiliary products, leather, textile, construction (pipe, plate, door, window, etc.), adhesives, grout, filling material, isolation material, photographic material, gunpowder and explosives like final and intermediate products are provided to many industrial areas.

When we evaluate the structure of chemical industry and its place globally, this industrial area is open to development and investment when we consider its close relations with all kinds of industrial production and its growing volume of trade. The findings of this study; in which the comparative advantages and competitiveness of Turkish Chemical Industry and the chemical industries of designated European Union countries are evaluated per Balassa's Revealed Comparative Advantage Index, indicate that Croatia, Hungary and Lithuania generally have rather high competitive advantage while Turkey, Poland and Latvia generally are lack of competitiveness. Although global economic crisis of 2008 adversely affected chemical industry as well as all areas, it is observed that the effects of the crisis are diminishing since 2010.

If, specially, Turkey, Poland and Latvia desire to improve their chemical industries to a structure with competitiveness, they have to develop and promote their own technologies in producing high-tech, high value added goods and sensible to environmental protection. For this reason, by promoting their Research and Development policies, they have to support the creation of R\&D culture in their sector. 


\section{REFERENCES}

Baltacı, A., Burgazoğlu, H. ve Kılıç, S., (2012), "Türkiye'nin Rekabetçi Sektörleri ve Trakya Bölgesi'nin Payı” Çankııı Karatekin Üniversitesi İktisadi ve İdari Bilimler Fakültesi Dergisi, C.2, S.1, pp. 1-19.

Ertek, E., (2014), Kimya Sektörü Raporu, TSKB Ekonomik Araştırmalar, http://www.tskb.com.tr/i/content/730 1 Kimya Sektor Raporu Agustos 2014.pdf, (5.03.2017)

Dereli D.D. (2015), "Innovation Management in Global Competition and Competitive Advantage", World Conference on Technology, Innovation and Entrepreneurship, Procedia - Social and Behavioral Sciences 195, pp. 1365 - 1370.

Doğan, E., (2016), “The Effect of Innovation on Competitiveness”, Ekonometri ve İstatistik Sayı: 24, 2016, pp. 60-81.

DPT (1979), Dördüncü Beş Yıllık Kalkınma Planı (1979-1983), Ankara.

DPT (1989), Altıncı Beş Yıllık Kalkınma Planı(1990-1994), Ankara.

DPT (1995), Yedinci Beş Yıllık Kalkınma Planı (1994-2000), Ankara.

DPT (2001), Sekizinci Beş Yıllık Kalkınma Planı Kimya Özel Ihtisas Komisyonu Raporu, Ankara.

DPT (2000), Sekizinci Beş Yıllık Kalkınma Planı (2000-2005), Ankara.

Duru, S. (2014), Kimya Sanayiinde Kümelenme: Kimya Parkları, T.C. Kalkınma Bakanlığı, Iktisadi Sektörler ve Koordinasyon Genel Müdürlüğü.

Fertö I. and Hubbard L. J. (2002), "Revealed Comparative Advantage and Competitiveness in Hungarian Agri-Food Sectors Technology Foresight in Hungary", KTK/IE Discussion Papers 2002/8 Institute of Economics Hungarian Academy of Sciences pp.1-23.

LIAA (2017), Chemical, Pharmaceutical and Biotechnological Industry, http://www.liaa.gov.lv/en/trade/industry-profiles/chemistrypharmacy-and-biotechnology-industry, (5.3.2017).

MAVESZ (2015), Chemical Industry in Hungary, 25th Anniversary Publication of the Hungarian Chemical Industry Association, March 2015, http://mavesz.hu/file/MAVESZ 25 kiadvany v8b EN 72dpi.pdf (20.03.2017).

Polish Information and Foreign Investment Agency (2013), Chemical Sector in Poland: Sector Profile, 2013, www.paih.gov.pl/files/?id_plik=21680, (20.03.2017).

Štibuhar, S. Picard, T. And Kovačev, K. (2014), Chemistry Industry in Croatia, Flanders Investment and Trade Market Survey, July 2014, https://www.flandersinvestmentandtrade.com/export/sites/trade/files/market studies/249140708104927/249140708104927 1.pdf, (20.03.2017).

T.C. Kalkınma Bakanlığı (2015), Onuncu Kalkınma Planı 2014-2018, Kimya Çalışma Grubu Raporu, Yayın No: KB: 2929, ÖiK: 756, Ankara.

T.C. Ekonomi Bakanlığı (2015), Kimya Sektörü, Sektör Raporları, Ankara.

UK Trade \& Investment, (2010), Sector Briefing: Chemical Industry Opportunities in Lithuania, https://s3.amazonaws.com/StagingContentBucket/pdf/20110321121933920.pdf, (20.03.2017).

Ulengin, Füsun. et. al. (2012), Kimya Sanayisi Rekabet Gücü Raporu, Ed. Emre Tamer, TÜsiAD-Sabancı Üniversitesi Rekabet Forumu (REF) ve Sektörel Dernekler Federasyonu (SEDEFED), Kasım 2012, istanbul.

UN, Commodity Trade Statistics Database (COMTRADE), http://comtrade.un.org/data/ (3.3.2017).

Utkulu, U. and Seymen D. (2004), "Revealed Comparative Advantage and Competitiveness: Evidence for Turkey vis-à-vis the EU/15", European Trade Study Group 6th Annual Conference, ETSG 2004, Nottingham, September 2004, pp. 1-26.

World Economic Forum (WEF) (2011), The Global Competitiveness Report 2016-2017, http://www3.weforum.org/docs/GCR20162017/05FullReport/TheGlobalCompetitivenessReport2016-2017 FINAL.pdf, (05.03.2017)

Yalçınkaya, H. et.al. (2014), “Açıklanmış Karşılaştırmalı Üstünlükler Endeksinde Rekabet Gücünün Analizi: Türk-Çin Dış Ticareti Üzerine Bir Uygulama", Yönetim ve Ekonomi Araştırmaları Dergisi, S.:24, ss. 41-57. (Doi: http://dx.doi.org/10.11611/JMER294)

Yue, C. and Ping H. (2002), “Does Comparative Advantage Explain Export Patterns in China?”, China Economic Review. 13: 276-296.

http://global.britannica.com/topic/chemical-industry (03.03.2017). 